\title{
The prevalence of orthostatic hypotension and its risk factors among 40 years and above adult population in Indonesia
}

\author{
Siti Setiati ${ }^{*}$, Bambang Sutrisna ${ }^{f}$, Wiguno Prodjosudjadi ${ }^{*}$
}

\begin{abstract}
Abstrak
Berbagai faktor yang berhubungan dengan hipotensi ortostatik, seperti umur, obat anti hipertensi, hipertensi, strok dan diabetes melitus masih diperdebatkan. Sampai saat ini belum ada data mengenai prevalensi hipotensi ortostatik di Indonesia. Sebagian besar penelitian hipotensi ortostatik yang ada di luar negeri dilakukan pada subjek berusia lanjut. Tujuan penelitian ini adalah untuk mendapatkan prevalensi hipotensi ortostatik di Indonesia dan faktor prediktor terjadinya hipotensi ortostatik pada orang berusia 40 tahun ke atas di Indonesia. Empat ribu empat ratus tiga puluh enam subjek berusia 40-94 tahun didapatkan secara random dari berbagai praktek dokter di berbagai kabupaten di Indonesia. Data dikumpulkan dengan melakukan serangkaian anamnesis (riwayat penyakit diabetes melitus, hipertensi, dan strok serta penggunaan obat anti hipertensi) dan pemeriksaan tekanan darah pada posisi tidur dan duduk setelah 1-3 menit. Regresi logistik multipel dilakukan untuk mendapatkan prediktor hipotensi ortostatik yang paling bermakna. Subjek yang mengalami hipotensi ortostatik sebesar 561 subjek (12,65\%). Analisis bivariat menunjukkan adanya hubungan antara riwayat diabetes melitus, riwayat strok, tekanan darah sistolik tinggi dan tekanan darah diastolik tinggi. Umur tidak berhubungan dengan hipotensi ortostatik. Hasil analisis multivariat mendapatkan tekanan darah sistolik tinggi dan tekanan darah diastolik tinggi sebagai prediktor hipotensi ortostatik. Penggunaan obat anti hipertensi merupakan faktor protektif terjadinya hipotensi ortostatik. Penelitian ini memastikan bahwa usia saja bukan merupakan prediktor terjadinya hipotensi ortostatik. Adanya komorbiditas seperti hipertensi (tekanan darah sistolik atau diastolik tinggi) merupakan prediktor terjadinya hipotensi ortostatik. Sedangkan obat anti hipertensi merupakan faktor protektif terjadinya hipotensi ortostatik. (Med J Indones 2004; 13: 180-9)
\end{abstract}

\begin{abstract}
Factors associated with orthostatic hypotension such as age, drug induced hypotension, hypertension and diabetes mellitus have still been debatable. Most of previous studies were conducted in subjects 65 years or older, only a few were done in subjects from younger to older adults. The purpose of this study is to find the prevalence and predictor factors of orthostatic hypotension among adult population aged 40 years and above in Indonesia. This study is a part of Indonesian Hypertension Epidemiologic Survey. A random sample of 4436 subjects aged 40-94 years was obtained from various municipalities in every big island in Indonesia. Orthostatic testing, assesment of history of medical conditions (diabetes mellitus, stroke, and hypertension), blood pressure measurement and use of anti-hypertensive medications were performed. A stepwise logistic regression was used to determine the significant predictor of orthostatic hypotension. A total of 561 persons (12.6\%) experienced orthostatic hypotension. Central $\alpha 2$-agonist and other centrally acting drug is the only anti hypertension medicine which influences orthostatic hypotension. Multivariate analysis showed that high systolic and diastolic blood pressures were predictor factors of orthostatic hypotension. The use of anti-hypertensive medicine was a protective factor for orthostatic hypotension. This study confirms the conclusion that age is not a predictor factor for orthostatic hypotension. In fact, the existence of comorbidities in the subjects such as hypertension (high systolic and diastolic blood pressure) is a predictor factor, while the use of anti-hypertensive medication is a protective factor. (Med J Indones 2004; 13: 180-9)
\end{abstract}

Keywords: adult, orthostatic hypotension, prevalence, risk factor

\footnotetext{
* Department of Internal Medicine, Faculty of Medicine University of Indonesia / Dr. Cipto Mangunkusumo Hospital, Jakarta, Indonesia

${ }^{f}$ Faculty of Public Health, University of Indonesia, Depok, Indonesia
}

Orthostatic hypotension is quite common in adults, especially in elderly population. It is believed to be an important cause of generalized cerebral hypoperfusion leading to dizziness, syncope, and falls, and it may be a cause of focal cerebral hypoperfusion as manifested by transient ischemic attacks. 
There are varying criteria for the diagnosis of orthostatic hypotension. Some authors define orthostatic hypotension as a fall of systolic blood pressure $\geq 20 \mathrm{mmHg}$ and/or diastolic blood pressure $\geq 10 \mathrm{mmHg}$ one to three minutes after the postural changes. ${ }^{2-5}$ A reading should be made when the patient is supine, immediately after assumption of the seated or upright position, and at two to three minute intervals. ${ }^{2,4,6}$ Orthostatic hypotension is also detected by measuring of blood pressure in two or more body positions. Blood pressure measurements determined in supine, $80^{\circ}$ tilt, and tilt back are considered useful to quantitate orthostatic failure in blood pressure control. $^{5}$ The most recent consensus is a drop in blood pressure of at least $20 \mathrm{~mm} \mathrm{Hg}$ systolic or $10 \mathrm{~mm} \mathrm{Hg}$ diastolic within three minutes of either standing or head-up tilt of at least $60^{\circ}{ }^{7}$ Our study measured blood pressure in supine and sitting positions (90 degree tilt) due to technical, practical, and epidemiological consideration.

Several risk factors for postural hypotension such as aging, bed rest, drug induced hypotension, hypertension and diabetes mellitus have been suggested; these associations have still been questioned and debatable. ${ }^{8}$ No big scale population study with longer age interval of subjects has been conducted in this case. Most of previous studies were done in subjects 65 years or older. This is the first and large scale population study in Indonesia (which has more than 200 million people) to determine the prevalence of orthostatic hypotension and its risk factors among adults aged 4094 years.

\section{METHODS}

\section{Study population and subjects}

This study is a part of the Indonesian epidemiologic hypertension survey. Multistage random sampling was used as a sampling method of this study. The subjects were Indonesian population aged $\geq 40$ years who lived at the cities or district areas and visited the private clinics for various reasons in June-July 2002. Subjects were randomly assigned due to visiting time for one to two weeks. Indonesia is divided into six units comprising of five big islands, Java, the most populous; Sumatra; Kalimantan; Sulawesi and Bali. Subjects in each unit were calculated by using the survey formula with $\alpha=0.05$, proportion of hypertension 0.5 and $\mathrm{d}=5$ percent. Because Java is the most populous island, five provinces in Java (East Java, Central Java, West Java, Jakarta, Jogjakarta), two provinces each for Sumatra (North Sumatra and South Sumatra) and Sulawesi (South Sulawesi and Central Sulawesi), one province each for Kalimantan (South Kalimantan) and Bali were assigned. Cities and district areas involved in the survey were randomly allocated for each province. Once the city and district area were assigned, two doctors were randomly appointed to take part in the survey. There were no exclusion criteria for this study. The total subjects participating in this study were 4436, which consisted of 2246 men and 2190 women.

\section{Variables}

The following variables were assessed, using standard structured questionaires: demographic characteristics, history of medical conditions (diabetes mellitus, stroke, and hypertension), and use of anti-hypertensive medication. Body weight and height, heart rate, supine and seated blood pressure were measured. Data were collected by two doctors from each chosen city.

\section{Blood pressure and heart rate measurements}

Blood pressure was measured by trained doctors using a mercury sphygmomanometer according to the standardized protocol. Blood pressure measurements were taken two times in supine and upright $\left(90^{\circ}\right.$ tilt $)$ seated positions. Supine blood pressure measurement was taken after 10 minute rest in supine position. The arm was held approximately in the horizontal position during the testing. Systolic blood pressure was recorded at the level when phase I Kortkoff sounds were first heard, and diastolic blood pressure was recorded at the beginning of phase $\mathrm{V}$ with the disappearance of sounds. ${ }^{9}$ All readings were recorded to the nearest even digit. After a supine blood pressure was obtained, the subject was assisted to a $90^{\circ}$ seated upright position immediately. The entire forearm was supported at heart level ( $4^{\text {th }}$ intercostal space). Seated blood pressure measurements were taken after one to three minutes seated. Each supine and seated blood pressure was then averaged. Thus, orthostatic measurement included the average supine blood pressure and the average one to three minutes seated $\left(90^{\circ}\right.$ tilt) blood pressure. Heart rate was measured in seated position by radialis artery palpation in minimally 30 seconds. The value obtained was then multiplied by two to get the heart rate in minutes. ${ }^{10}$ 


\section{Definitions of clinical measurements}

Orthostatic hypotension is defined as a drop of systolic blood pressure of $20 \mathrm{mmHg}$ or more and/or a decline of diastolic blood pressure of $10 \mathrm{mmHg}$ or more from supine position to seated $\left(90^{\circ}\right)$ position. ${ }^{2,3,4,5}$ Hypertension is defined as the average of both supine systolic and diastolic blood pressure $\geq 140 / 90 \mathrm{mmHg}$, and graded into three stages, hypertension stage $\mathrm{I}$ if systolic blood pressure $140-159 \mathrm{mmHg}$ or diastolic blood pressure $90-99 \mathrm{mmHg}$, hypertension stage II if systolic blood pressure $160-179 \mathrm{mmHg}$ or diastolic blood pressure 100-109 $\mathrm{mmHg}$, and hypertension stage III if systolic blood pressure $\geq 180 \mathrm{mmHg}$ or diastolic blood pressure $\geq 110 \mathrm{mmHg} .{ }^{9}$ Diabetes mellitus is defined as a positive response to medical history of diabetes or current use of insulin or oral hypoglycemic agent. ${ }^{11}$ Stroke is defined as a positive response to the medical history of stroke or the presence of hemiparesis, motor rigidity, and asymetric hyperreflexia. ${ }^{11}$ Body Mass Index (BMI) is obtained from the calculation of body weight $(\mathrm{kg}) /$ body height $(\mathrm{m})^{2}$, and is classified into three classifications: underweight if $\mathrm{BMI}$ less than 17 for woman and less than 18 for man, normal if BMI 17-23 for woman and
18-25 for man, overweight if BMI more than 23 for woman and more than 25 for man. ${ }^{12}$

\section{Statistical analyses}

Data analysis was begun by determining the number of orthostatic hypotension. The Stata software version 7.0. was used for data analysis. The comparison of continuous variables was performed with the independent student's $t$ test. X2 test was used to compare categorical variables. Stepwise multiple logistic regression was used to asses the association of clinical variables with orthostatic hypotension and to determine variables which were significant as risk factors of orthostatic hypotension. Statistical significance was set at 0.05 .

\section{RESULTS}

Orthostatic hypotension was found in 12.6 percent of subjects (561 of 4436). The characteristics of subjects with and without orthostatic hypotension are shown in Table 1. There were no differences in age, sex, body weight, body height, body mass index, systolic seated blood pressure and heart rate.

Table 1. Characteristics of subjects with and without orthostatic hypotension among adult population in Indonesia in 2002

\begin{tabular}{|c|c|c|c|}
\hline \multirow[b]{2}{*}{ Characteristics } & \multicolumn{2}{|c|}{ Orthostatic hypotension } & \multirow[b]{2}{*}{$\begin{array}{l}2 \text { sided } \\
p \text { values }\end{array}$} \\
\hline & $\begin{array}{c}\text { Yes } \\
(\mathrm{n}=561)\end{array}$ & $\begin{array}{c}\text { No } \\
(\mathrm{n}=3875)\end{array}$ & \\
\hline \multicolumn{4}{|l|}{ Sex } \\
\hline Male & $285(50.82 \%)$ & $1961(50.61 \%)$ & 0.93 \\
\hline Female & $276(49.20 \%)$ & $1914(49.39 \%)$ & \\
\hline \multicolumn{4}{|l|}{ Education } \\
\hline No formal education & $47(8.38 \%)$ & $268(6.93 \%)$ & 0.00 \\
\hline Elementary school & $191(34.05 \%)$ & $923(23.82 \%)$ & \\
\hline Junior high school & $98(17.47 \% \%)$ & $672(17.34 \%)$ & \\
\hline Senior high school & $154(27.45 \%)$ & $1398(36.08 \%)$ & \\
\hline Academy/university & $71(12.66 \%)$ & $614(15.85 \%)$ & \\
\hline Age (years) & $54.04(10.06)$ & $53.36(10.19)$ & 0.14 \\
\hline Body height (m) & $157.99(8.40)$ & $158.72(8.42)$ & 0.06 \\
\hline Body weight (Kg) & $59.48(11.84)$ & $59.62(11.21)$ & 0.80 \\
\hline Body mass index $\left(\mathrm{kg} / \mathrm{m}^{2}\right)$ & $23.81(4.29)$ & $23.65(4.18)$ & 0.43 \\
\hline \multicolumn{4}{|l|}{ Supine blood pressure } \\
\hline Systolic blood pressure & $145.30(29.92)$ & $134.07(24.41)$ & 0.00 \\
\hline Diastolic blood pressure & $92.24(15.23)$ & $83.84(12.39)$ & 0.00 \\
\hline \multicolumn{4}{|l|}{ Seated blood pressure } \\
\hline Systolic blood pressure & $134.14(28.85)$ & $133.39(24.54)$ & 0.51 \\
\hline Diastolic blood pressure & 83.04 (15.27) & 84.64 (12.48) & 0.01 \\
\hline Heart rate (beats/min) & $81.02(12.09)$ & $80.19(23.23)$ & 0.19 \\
\hline
\end{tabular}

Values are mean(SD) except sex and education 
The comparison of some possible risk factors of orthostatic hypotension in subjects with and without orthostatic hypotension is given in Table 2. From the bivariate analysis, we found systolic hypertension, diastolic hypertension, history of stroke and history of diabetes mellitus were associated with orthostatic hypotension. On the other hand, there was no association between age and body mass index with orthostatic hypotension. From 4436 subjects, there were 3080 subjects who answered the question about the use of anti-hypertensive medication and $13.99 \%$ of them had orthostatic hypotension. Table 3 shows that the use of anti-hypertensive medication was not associated with orthostatic hypotension.

One hundred ninety five subjects using anti-hypertensive medication did not know the type/name of their antihypertensive medication. It means 1067 subjects knew the type/name of their anti-hypertensive medication and $13.78 \%$ of them had orthostatic hypotension.
Estimated odds ratio of type anti-hypertensive medication and orthostatic hypotension is given in table 4. Central $\alpha_{2}$-agonist is the only antihypertension medicine which influences orthostatic hypotension $(\mathrm{OR}=1.99)$.

In the multivariate analysis, all significant and possible risk factors from bivariate analysis were assessed by logistic regression. The association between history of diabetes mellitus and stroke with orthostatic hypotension dissapeared. The use of antihypertensive medication, systolic and diastolic hypertension were associated with orthostatic hypotension. Systolic and diastolic hypertension were proven as risk factors, while the use of anti-hypertensive medication was the protective factor of orthostatic hypotension. The higher the blood pressure, the higher the percentage of orthostatic hypertension. The association between age (aging) and diabetes mellitus with orthostatic hypotension was not proven.

Table 2. Estimated odds ratios of orthostatic hypotension with certain variables from bivariate analysis among adult population in Indonesia in 2002

\begin{tabular}{|c|c|c|c|c|c|c|c|}
\hline \multirow{3}{*}{ Variables } & \multicolumn{4}{|c|}{ Orthostatic hypotension } & \multirow{3}{*}{ OR } & \multirow{3}{*}{$95 \% \mathrm{CI}$} & \multirow{3}{*}{$\begin{array}{l}2 \text { sided } \\
p \text { value }\end{array}$} \\
\hline & \multicolumn{2}{|c|}{$\begin{array}{c}\text { Yes } \\
(n-561)\end{array}$} & \multicolumn{2}{|c|}{$\begin{array}{c}\text { No } \\
(n=3875)\end{array}$} & & & \\
\hline & $\mathrm{n}$ & $\%$ & $\mathrm{~N}$ & $\%$ & & & \\
\hline \multicolumn{8}{|l|}{ Age } \\
\hline $40-59$ years & 386 & 68.81 & 2784 & 71.85 & 1.00 & & \\
\hline $60-69$ years & 122 & 21.75 & 755 & 19.48 & 1.16 & $0.94,1.45$ & 0.17 \\
\hline $70-79$ years & 46 & 8.20 & 268 & 6.92 & 1.24 & $0.89,1.72$ & 0.20 \\
\hline$\geq 80$ years & 7 & 1.25 & 68 & 1.75 & 0.74 & $0.34,1.63$ & 0.46 \\
\hline \multicolumn{8}{|l|}{ Sex } \\
\hline Female & 276 & 49.20 & 1914 & 49.39 & 1.00 & & \\
\hline Male & 285 & 50.80 & 1961 & 50.61 & 1.01 & $0.84,1.20$ & 0.93 \\
\hline \multicolumn{8}{|l|}{ Body mass index } \\
\hline Normal & 287 & 51.16 & 2002 & 51.66 & 1.00 & & \\
\hline Underweight & 37 & 6.60 & 199 & 5.14 & 1.29 & $0.89,1.88$ & 0.17 \\
\hline Overweight & 237 & 42.25 & 1674 & 43.20 & 0.99 & $0.82,1.19$ & 0.89 \\
\hline \multicolumn{8}{|l|}{ History of Diabetes Mellitus } \\
\hline No & 492 & 87.70 & 3502 & 90.37 & 1.00 & $1.00,1.73$ & 0.049 \\
\hline Yes & 69 & 12.30 & 373 & 9.63 & 1.32 & & \\
\hline \multicolumn{8}{|l|}{ History of stroke } \\
\hline No & 535 & 95.37 & 3777 & 97.47 & 1.00 & & \\
\hline Yes & 26 & 4.63 & 98 & 2.53 & 1.87 & $1.204,2.913$ & 0.005 \\
\hline \multicolumn{8}{|l|}{ Supine systolic hypertension } \\
\hline Not hypertension & 249 & 44.39 & 2356 & 60.8 & 1.00 & & \\
\hline Hypertension stage I & 107 & 19.07 & 810 & 20.10 & 1.25 & $0.98,1.59$ & 0.07 \\
\hline Hypertension stage II & 108 & 19.25 & 464 & 11.47 & 2.20 & $1.72,2.82$ & 0.00 \\
\hline Hypertension stage III & 97 & 17.29 & 245 & 6.32 & 3.75 & $2.86,4.90$ & 0.00 \\
\hline
\end{tabular}


Table 2. Estimated odds ratios of orthostatic hypotension with certain variables from bivariate analysis among adult population in Indonesia in 2002

\begin{tabular}{|c|c|c|c|c|c|c|c|}
\hline \multirow{3}{*}{ Variables } & \multicolumn{4}{|c|}{ Orthostatic hypotension } & \multirow{3}{*}{ OR } & \multirow{3}{*}{$95 \% \mathrm{CI}$} & \multirow{3}{*}{$\begin{array}{c}\text { Two sided } p \\
\text { value }\end{array}$} \\
\hline & \multicolumn{2}{|c|}{$\begin{array}{c}\text { Yes } \\
(n-561)\end{array}$} & \multicolumn{2}{|c|}{$\begin{array}{c}\text { No } \\
(\mathrm{n}=3875)\end{array}$} & & & \\
\hline & $\mathrm{n}$ & $\%$ & $\mathrm{n}$ & $\%$ & & & \\
\hline \multicolumn{8}{|l|}{ Supine diastolic hypertension } \\
\hline Not hypertension & 201 & 35.83 & 2434 & 62.81 & 1.00 & & \\
\hline Hypertension stage I & 152 & 27.09 & 907 & 23.41 & 2.03 & $1.62,2.54$ & 0.00 \\
\hline Hypertension stage II & 97 & 17.29 & 353 & 9.11 & 3.33 & $2.55,4.34$ & 0.00 \\
\hline Hypertension stage III & 111 & 19.79 & 181 & 4.67 & 7.43 & $5.63,9.79$ & 0.00 \\
\hline \multicolumn{8}{|l|}{ Seated systolic hypertension } \\
\hline Not hypertension & 326 & 38.11 & 2398 & 61.88 & 1.00 & & \\
\hline Hypertension stage I & 96 & 17.11 & 769 & 19.85 & 0.92 & $0.72,1.17$ & 0.00 \\
\hline Hypertension stage II & 85 & 15.15 & 478 & 12.34 & 1.31 & $1.01,1.69$ & 0.00 \\
\hline Hypertension stage III & 54 & 9.63 & 230 & 9.63 & 1.73 & $1.26,2.38$ & 0.00 \\
\hline \multicolumn{8}{|l|}{ Seated diastolic hypertension } \\
\hline Not hypertension & 341 & 60.78 & 2341 & 60.41 & 1.00 & & \\
\hline Hypertension stage I & 102 & 8.18 & 935 & 24.13 & 0.75 & $0.59,0.95$ & 0.01 \\
\hline Hypertension stage II & 76 & 13.55 & 403 & 10.40 & 1.29 & $0.98,1.69$ & 0.06 \\
\hline Hypertension stage III & 42 & 7.49 & 196 & 5.06 & 1.47 & $1.03,2.09$ & 0.03 \\
\hline
\end{tabular}

Table 3. Estimated odds ratios of orthostatic hypotension with use of antihypertensive medication among adult population in Indonesia in 2002

\begin{tabular}{|c|c|c|c|c|c|c|c|}
\hline \multirow{3}{*}{ Variables } & \multicolumn{4}{|c|}{ Orthostatic hypotension } & \multirow{3}{*}{ OR } & \multirow{3}{*}{$95 \% \mathrm{CI}$} & \multirow{3}{*}{$\begin{array}{c}\text { Two sided } p \\
\text { value }\end{array}$} \\
\hline & \multicolumn{2}{|c|}{$\begin{array}{c}\text { Yes } \\
(n-431)\end{array}$} & \multicolumn{2}{|c|}{$\begin{array}{c}\text { No } \\
(\mathrm{n}=2649)\end{array}$} & & & \\
\hline & $\mathrm{n}$ & $\%$ & $\mathrm{n}$ & $\%$ & & & \\
\hline \multicolumn{8}{|c|}{$\begin{array}{l}\text { Use of antihypertensive } \\
\text { medication }\end{array}$} \\
\hline Yes & 189 & 43.85 & 1073 & 40.51 & 1.15 & $0.93,1.41$ & 0.19 \\
\hline No & 242 & 56.15 & 1576 & 59.49 & 1.00 & & \\
\hline
\end{tabular}


Table 4. Estimated odds ratios of orthostatic hypotension with use of antihypertensive medication among adult population in Indonesia in 2002

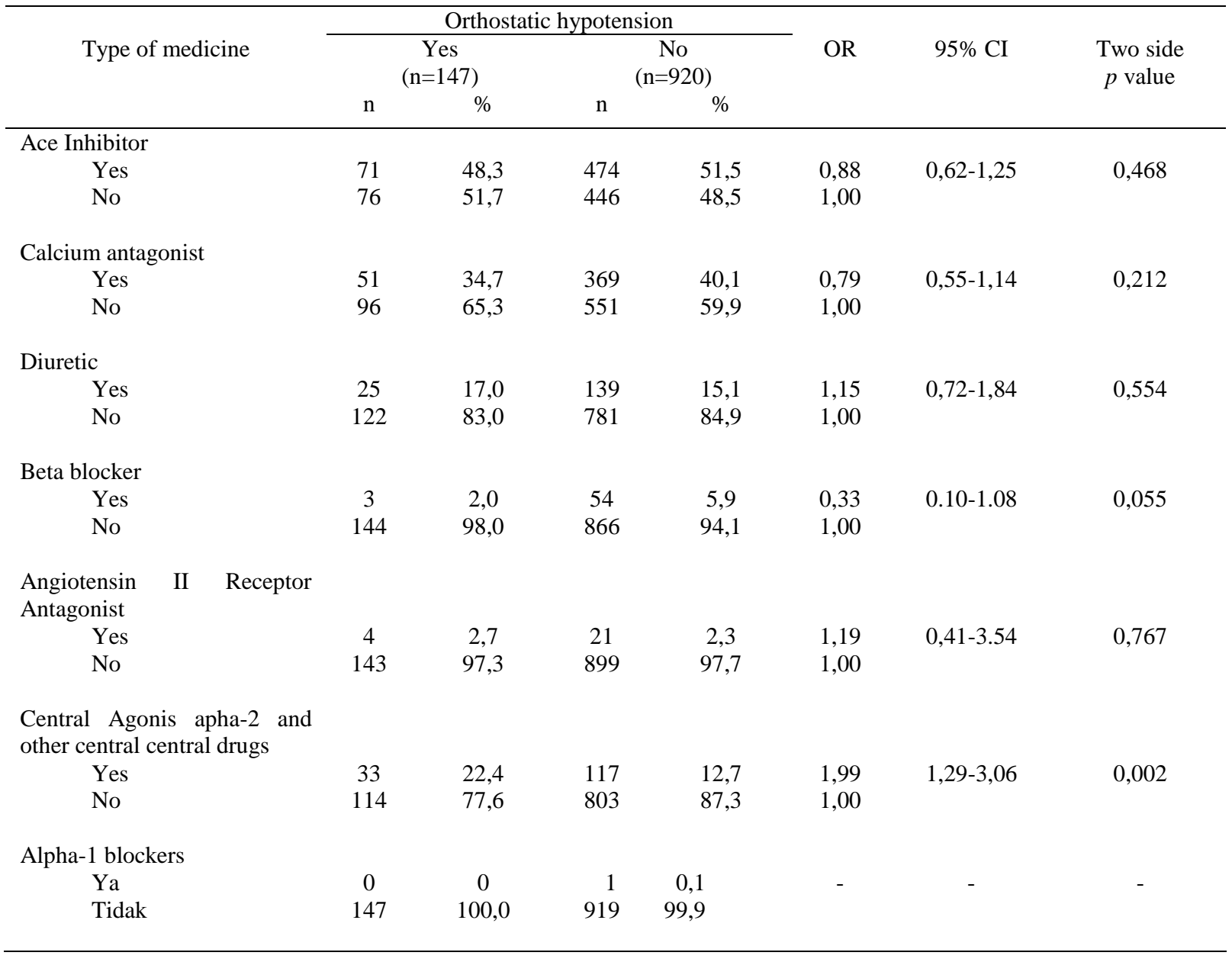

Table 5. Estimated odds ratios of orthostatic hypotension with certain variables from multiple logistic regression

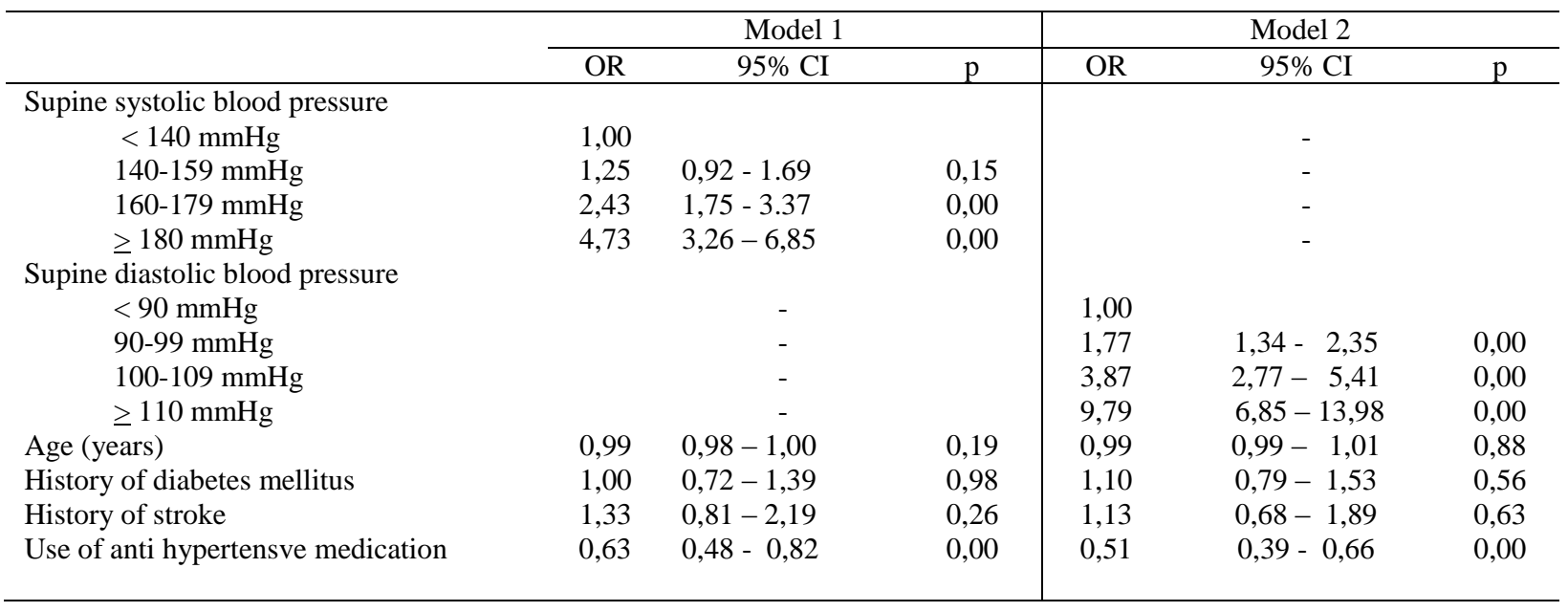


Table 6. Coeffisient and standard error value in the model

\begin{tabular}{lcccc}
\hline & \multicolumn{2}{c}{ Model 1 } & \multicolumn{2}{c}{ Model 2 } \\
\cline { 2 - 5 } & Coeffisient & Std. eror & Coeffisient & Std. eror \\
\hline Constants & $-2,03$ & 0,083 & $-2,22$ & 0,09 \\
Supine systolic hypertension & & & & \\
$<140 \mathrm{mmHg}$ & 0,19 & 0,15 & & \\
$140-159 \mathrm{mmHg}$ & 0,86 & 0,16 & & \\
$160-179 \mathrm{mmHg}$ & 1,52 & 0,18 & & \\
$\geq 180 \mathrm{mmHg}$ & & & 0,58 & 0,14 \\
Supine diastolic hypertensiom & & & 1,35 & 0,17 \\
$\quad<90 \mathrm{mmHg}$ & & & 2,29 & 0,18 \\
$90-99 \mathrm{mmHg}$ & & & & \\
$100-109 \mathrm{mmHg}$ & $-0,46$ & 0,14 & $-0,66$ & 0,13 \\
$\quad$ >110 mmHg & & & & \\
Anti-hypertensive medication & & &
\end{tabular}

\section{DISCUSSION}

This study was a part of the Indonesian Epidemiologic Hypertension Survey in 2002. It was carried out with probability sampling (multistage random sampling) among adult population aged 40 years and above in Indonesia. As the Indonesian population is more than 200 million people, this study is expected to represent orthostatic hypotension prevalence in bigger populations in the world.

There are varying criteria for the diagnosis of orthostatic hypotension. Some authors defined orthostatic hypotension as a decline systolic and/or diastolic blood pressure from supine to standing positions., ${ }^{3,13}$ Some other authors suggested to take blood pressure measurement in two or more body positions. ${ }^{11} \mathrm{~A}$ reading should be made when the patient is supine, immediately after assumption of the upright seated or standing position, and at two to three minute intervals for five minutes. ${ }^{4}$ The most recent consensus is a drop in blood pressure of at least $20 \mathrm{~mm} \mathrm{Hg}$ systolic or 10 $\mathrm{mm} \mathrm{Hg}$ diastolic within three minutes of either standing or head-up tilt of at least $60^{\circ} .7$ Blood pressure measurements determined in supine, $80^{\circ}$ tilt, and tilt back are considered useful to quantitate orthostatic failure in blood pressure control. ${ }^{5}$ Our study measured blood pressure in supine and upright sitting positions (90 degree tilt) due to technical, practical and epidemiological study consideration. The arm was passively supported at the level of the heart during the measurement of blood pressure.

The prevalence of orthostatic hypotension in this study is relatively high, that is 12.6 percent. Other surveys show a wide variation in prevalence from four percent to 33 percent. However, several methodological factors influence both the estimated prevalence of orthostatic hypotension and the measured changes of blood pressure in response to postural challenges, including the number of baseline blood pressure measurements, starting position (supine versus seated), arm supported during standing, timing of blood pressure measurement after standing/seated. ${ }^{1}$

Orthostatic hypotension is reported have occured frequently in elderly population. However, the findings regarding the effect of age on orthostatic hypotension have been contradictory with one another. Many studies were based on subjects with diseases and on medications known to cause orthostatic hypotension, which confused the relative contributions of normal aging, diseases, and medication effects.

Our studies revealed that age alone was not associated with orthostatic hypotension which was consistent with some other studies. ${ }^{1,8,14}$ A National Health and Nutrition Examination Survey was conducted in 1976-1985 on 8000 participants, in which Lipsitz LA stated that orthostatic hypotension was actually due primarily to an age associated increase in the systolic blood pressure in the supine position. ${ }^{15}$ Since the number of subjects in our study was large and randomly selected (as the study done by Lipsitz et al) we are convinced that comorbidities, especially hypertension, is the major determinants of orthostatic hypotension. In relation to the result of the National Health and Nutrition Examination Survey conducted by Lipsitz et al, our study also indicates that an increase occurs not only in systolic blood pressure, 
but also in diastolic blood pressure in supine position, that is associated with orthostatic hypotension.

A study done by $\mathrm{Wu}$, et $\mathrm{al}^{7}$ found that the prevalence of orthostatic hypotension in three groups of age $(<40$ years, 40-64 years, and $\geq 65$ years) were $7.8 \%$, $17.4 \%$, and $25,0 \%$. In our study, if subjects were divided into two groups of age namely 40-64 years and $\geq 65$ years, the prevalence of orthostatic hypotension was higher in older subjects $(14.04 \%$ vs $12.36 \%$ ). It was consistent with study which is done by $\mathrm{Wu}$, et al (1999). If subjects were divided into four groups $(40-59,60-69,70-79, \geq 80$ years), the prevalence of orthostatic hypotension were $12.18 \%$, $13.91 \%, 14.65 \%, 9.33 \%$. Subjects in $60-69$ and $70-79$ age groups had higher prevalence of orthostatic hypotension, althought it was not statistically significant. In younger age of group (40-59 years) in this study, orthostatic hypotension was $12.18 \%$. Orthostatic hypotension in this group of age might be caused by the influence of other factors such as deterioration of autonomic, and cardiovascular function. Although age is not statistically significant in bivariate analysis, because theoretically age is an important predictor of orthostatic hypotension, it is involved in multivariate analysis. In multivariate analysis, age is also not statictically significant.

The possitive association between age and orthostatic hypotension is shown in studies done by $\mathrm{Wu}$, et al, ${ }^{11}$ and $\mathrm{Wu}$, et $\mathrm{al}^{7}$. In another study, age was not correlated with orthostatic hypotension. ${ }^{14}$ Our study found that age was not correlated with orthostatic hypotension. The mechanism of association between age and orthostatic hypotension was still unclear. But, some age-related physiologic changes would be expected to favor development of orthostatic hypotension, such as decline in baroreflex sensitivity, arterial and cardiac compliance, increased venous tortuosity, decreased renal sodium conservation, plasma volume, renin, angiotensin, and aldosterone levels. It seems that comorbidities such as hypertension and other cardiovascular diseases influence orthostatic hypotension more rhan age alone in elderly.

Hypertension is the most important predictor factor of orthostatic hypotension. Our study found that sistolic and diastolic blood pressure correlated with orthostatic hypotension. It is relevant with other studies done by $\mathrm{Wu}$, et $\mathrm{al}^{7}$. We graded hypertension into 4 stages according to JNC. We found that the higher the stage of systolic and diastolic hypertension, the more risk of orthostatic hypotension increased. Hypertension has been shown to be associated with impaired baroreflex sensitivity, which may be due to a decrease in vascular compliance and consequent diminution of baroreceptor stretch and relaxation during transient changes in arterial blood pressure. An increase in blood pressure and duration of hypertension exacerbates the decline in baroreflex sensitivity that may, in part, be responsible for orthostatic hypotension. ${ }^{11}$

Our results showed orthostatic hypotension in 15.6 percent of 442 subjects with history of diabetes mellitus and 21.0 percent of 124 subjects with history of stroke. The association between the history of diabetes mellitus and the history of stroke with orthostatic hypotension occurred in bivariate analysis. However, in multivariate analysis, this asscociation dissapeared. $\mathrm{Wu}$ et al found significant association between diabetes and orthostatic hypotension in 119 persons with orthostatic hypotension. Rutan et al found no significant association between diabetes mellitus and orthostatic hypotension in older adults. ${ }^{1}$ Reaven and colleagues also found no relation between orthostatic hypotension and glucose tolerance in 2233 free-living participants aged 50-89 years. ${ }^{16}$ Despite the fact that diabetes is associated with symphatetic dysfunction, the lack of association between diabetes and orthostatic hypotension in our study suggests that most persons with diabetes do not have orthostatic hypotension. As for the mechanism of orthostatic hypotension in diabetes, there is more commonly a neurogenic cause usually associated with efferent involvement and rarely with afferent involvement of the baroregulatory reflex arc. Poor glycemic control of diabetes mellitus and duration of diabetes are considered to be able to affect orthostatic hypotension. Reported studies have revealed that poor glycemic control of diabetes mellitus, which is shown by increasing plasma glycosylated hemoglobin levels, is vulnerable to postural hypotension. Duration of diabetes has often been perceived as an associated factor of orthostatic hypotension, but the evidence is sparse. The prevalence of orthostatic hypotension (the criteria of orthostatic hypotension with a systolic blood pressure change of $30 \mathrm{~mm} \mathrm{Hg}$ or more) increased with the duration of diabetes in a young group (aged 18-34 years). Unfortunately, in this study we did not collect the data about the duration and glycemic control of diabetes. History of diabetes in this study is only based on anamnesis and history of the use of anti-diabetic agents. 
It is often assumed that the prevalence of orthostatic hypotension, especially in elderly, is increased by the use of anti-hypertensive agents, although there are reports suggesting that such a treatment has little effect on orthostatic blood pressure control. Fotherby et al demonstrated that withdrawal of anti-hypertensive therapy reduce the prevalence of orthostatic hypotension. ${ }^{17}$ In contrast, Martin et al found that diuretic therapy used by hypertensive subjects does not necessarily result in postural hypotension. ${ }^{14}$ Our study showed that anti-hypertensive medication was surprisingly a protective factor for the incidence of orthostatic hypotension (odds ratio $=0.65$ ). This phenomenon might be due to the positive effect of medication on hypertension, which was eventually followed by reducing orthostatic hypotension incidence.

We found that Alpha blocking agent and Central $\alpha 2$ agonist and other centrally acting drug are associated with orthostatic hypotension. Alpha blocking agent and Central $\alpha 2$-agonist and other centrally acting drug are worked by inhibit adrenergic neuron stimulation in central nervous system (sympatolitic). This may cause the decrease of cardiac response to simpatic stimulation and the decrease of heart rate cardiac which finally may cause orthostatic hypotension.

Alpha-1 blocking agent often cause orthostatic hypotension. But in this study, we did not find the association between Alpha-1 blocking agent with orthostatic hypotension, because only $0.1 \%$ of subjects who used Apha blocking agents. In this study, the association of diuretic agent was also not found, which is consistent with the study done by Myers, et al. Rutan et al found orthostatic hypotension to be weakly related to the use of beta blocking and vasodilating agents, but not with diuretics, angiotensin converting enzyme inhibitors or alpha-receptorblocking agents. Another study of 12 elderly patients with systolic hypertension submitted to orthostatic stress on a tilt table before and one year after $50 \mathrm{mg}$ hydrochlorothiazide daily, found such treatment resulted in no significant hypotensive episodes. Their subjects were well and without evidence of significant orthostatic hypotension treatment.

Several studies have been done to find the association between body mass index and orthostatic hypotension. ${ }^{7,11}$ Our study found no association between body mass index and orthostatic hypotension, which is consistent with the study done by Wu et al. ${ }^{7}$
Limitation of our study was the accuracy of medical history of the subjects, especially history of diabetes mellitus. We had history of diabetes mellitus only when there was a positive response to medical history of diabetes, or current use of insulin or oral hypoglycemic agent, but we did not measure the plasma glucose.

\section{CONCLUSION}

The prevalence of orthostatic hypotension in 40 years and older adults in Indonesia was 12.6 percent. Our results demonstrated that systolic hypertension and diastolic hypertension are independently risk factors of orthostatic hypotension, while surprisingly the use of anti-hypertension medication is a protective factor. Dose response relationship was noted; the higher the blood pressure, the higher the percentage of orthostatic hypotension. Alpha blocking agent and Central $\alpha 2$-agonist and other centrally acting drug is the only anti hypertension medicine which influences orthostatic hypotension. This study confirms the conclusion that age and diabetes mellitus are not risk factors for orthostatic hypotension. As the number of subjects was big and randomly selected, we believe that this study can be generalized to more than 200 million Indonesian people. Blood pressure measurement in supine and sitting positions can be used to detect orthostatic hypotension in population, rather than in supine and standing position measurement.

\section{Acknowledgment}

We thank steering committee of Indonesian Hypertension Epidemiologic Survey Drs. Manoefris Kasim, Aan Soenarta, Pudji Rahardjo, Lucky Aziza, Ginova Naenggolan, Samino, Andradi for their help and constructive criticism during the preparation of this manuscript.

\section{REFERENCES}

1. Rutan HG, Hermanson B, Bild DE, et al. Orthostatic hypotension in older adults the cardiovascular health study. Hypertension 1992;19(6):508-19.

2. Kenny RS. Falls and syncope. In:Evans JG, Williams TF, Beattie BL, et al., eds. Oxford textbook of geriatric medication. 2nd ed. New York, Oxford University Press, 2000:111-24.

3. Aronow WS. Dizziness and syncope. In: Hazzard WR, Blass JP, Ettinger WH, et al., eds. Principles of geriatric 
medication and gerontology. 4th ed. New York, McGraw-Hill, 1999:1519-34.

4. Porth CM. Alterations in blood pressure: hypertension and orthostatic hypotension. In: Porth CM, eds. Pathophysiology. 5th ed. Philadelphia, JB Lippincott-Raven Publishers, 1998:363-84.

5. Martin JB, Engstrom JW. Disorders of the autonomic nervous system. In: Braunwald, Fauci, Kasper, et al., eds. Principles of internal medication. Harrison's 15 th edition.. USA, McGraw-Hil, 2000:2416-20.

6. Curtis $\mathrm{R}, \mathrm{McDonald} \mathrm{S}$. Alterations in motor function. In:Porth CM., eds. Pathophysiology. 5th ed. Philadelphia, JB Lippincott-Raven Publishers, 1998:921-57.

7. Wu JS, Lu FW, Yang YC, et al. Postural hypotension and postural dizziness in patients with non-insulin dependent diabetes. Arch Intern Med 1999;159:1350-6.

8. Raiha I, Luutonen S, Piha J, et al. Prevalence, risk factors, and prognostic importance of postural hypotension. Arch Intern Med 1995;155:930-5.

9. Joint National Committee on Detection, Evaluation, and Treatment of High Blood Pressure. The sixth report of the joint national committee on prevention, detection, evaluation, and treatment of high blood pressure. Arch Intern Med 1997;157:2413-40.
10. Talley NJ, O'connor S. Clinical examination a systemic guide to physical diagnosis. Australia, MacLennan \& Petty Pty Limited,1996.

11. Wu JS, Wu NH, Lu FH, et al. Factors associated with orthostatic hypotension in the Chinese population in Taiwan. AJH 1996;9:999-1005.

12. Soejono $\mathrm{CH}$. Gizi pada usia lanjut (Nutrition in elderly). In: Soejono $\mathrm{CH}$, Setiati S, Nasrun MWS, et al., eds. Pedoman pengelolaan kesehatan pasien geriatri untuk dokter dan perawat (Manual of geriatric health care for doctor and nurse). Jakarta, PIP-FKUI, 2000:25-34.

13. Kane RL, Ouslander JG, Abrass IB. Essential of Clinical Geriatrics. New York, McGraw-Hill, 1994:197-220.

14. Myers MG, Kearns PM, Kennedy DS, Fisher RH. Postural hypotension and diuretic therapy in the elderly. CMA Journal 1978;119:581-5.

15. Lipsitz LA. Orthostatic hypotension in the elderly. The New England Journal of Medication 1989;321(14):952-7.

16. Reaven PD, Barrett-Connor EL, Browner DK. Abnormal glucose tolerance and hypertension. Diabetes Care 1990;13:119-25.

17. Fotherby MD, Potter JF. Orthostatic hypotension and antihypertensive therapy in the elderly. Postgrad Med K 1994;70:878-81. 